\title{
LONG-TERM CHANGES IN THE WATER TEMPERATURE OF RIVERS IN LATVIA
}

\author{
Inese Latkovska ${ }^{1,2}$ \# and Elga Apsite ${ }^{1}$ \\ ${ }^{1}$ Faculty of Geography and Earth Sciences, University of Latvia, Jelgavas iela 1, Rīga LV-1004, LATVIA, \\ e-mail: inesepallo@inbox.Iv \\ 2 Latvian Environment, Geology, and Meteorology Centre, Maskavas iela 165, Rīga LV-1019, LATVIA \\ \# Corresponding author
}

Communicated by Māris Kḷaviṇš

\begin{abstract}
The study describes the trends of monthly mean water temperature (from May to October) and the annual maximum water temperature of the rivers in Latvia during the time period from 1945 to 2000. The results demonstrated that the mean water temperatures during the monitoring period from May to October were higher in the largest rivers (from $13.6^{\circ} \mathrm{C}$ to $16.1^{\circ} \mathrm{C}$ ) compared to those in the smallest rivers (from $11.5^{\circ} \mathrm{C}$ to $15.7^{\circ} \mathrm{C}$ ). Similar patterns were seen for the maximum water temperature: in large rivers from $22.9^{\circ} \mathrm{C}$ to $25.7^{\circ} \mathrm{C}$, and in small rivers from $20.8^{\circ} \mathrm{C}$ to $25.8^{\circ} \mathrm{C}$. Generally, lower water temperatures occurred in rivers with a high groundwater inflow rate, for example, in rivers of the Gauja basin, in particular, in the Amata River. Mann-Kendall test results demonstrated that during the monitoring period from May to October, mean water temperatures had a positive trend. However, the annual maximum temperature had a negative trend.
\end{abstract}

Key words: water temperature, long-term changes, river, Latvia.

\section{INTRODUCTION}

The water temperature is among the physical characteristics of the surface water that has a direct impact on the flora and fauna in the water ecosystems, as an increase of water temperature very often has a negative impact on water quality (Webb and Nobilis, 1995). An increased water temperature, for example, promotes eutrofication (Webb and Nobilis, 1995; Poole et al., 2001; Jurgelènaitè et al., 2012). Changes in the river water temperatures also affect other processes such as the formation of the ice (ice starts to form when the water temperature falls below $\left.0{ }^{\circ} \mathrm{C}\right)$, chemical and biological processes (for example, volume of dissolved gases, rate of various chemical reactions, and activity of organisms), the volume of flow of dissolved substances due to mineralisation and chemical composition. Water temperature is also an essential indicator in the economy, for example, in cooling systems and for household needs (Mihailov et al., 2005).

The dynamics of river water temperature is complicated and can be studied at various scales: on a macroscale (the location of a river in various latitude and altitude, and continentality), on a mezoscale (climate and hydrology of the river basin), and microscale (river geometry, shadowing of banks and soils in the river basin) (Garner et al., 2013). The distribution of the water temperature in rivers is mainly determined by local physical geographic and anthropogenic fac- tors, of which the following are the most important: climate conditions, the surrounding landscape (forests, an open field), the inflow of groundwater, the distribution of sandy soils and lakes in the inflow basin, the size of the river and its geomorphology, as well as hydropower plants located on the river (Webb et al., 1996; Uehlinger et al., 2003; Carrivick et al., 2012; Jurgelènaitè et al., 2012; Gebre et al., 2014). A number of global studies have shown that among anthropogenic factors, hydro power plants have the largest impact on river water temperature (Prats et al., 2010, Jurgelẻnaité et al., 2012; Dickson et al., 2012). In densely populated areas large impact is also caused by waste water emitted to the river and the water collection points (Xin and Kinouchi, 2013).

The studies that have been recently performed worldwide on change in river water temperature are mainly related to the evaluation of the impact caused by climate change (Caissie, 2006; Arai, 2009; Kaushal et al., 2010; Prats et al., 2010; Van Vliet et al., 2011). The thermal regime of rivers depends on climate conditions, particularly solar radiation, and thereby water temperature directly depends on the air temperature. A close correlation between air and water temperatures has been documented, which indicates that the change in river water temperature is a direct result of the climate change (Kaushal et al., 2010; Prats et al., 2010; Floury et al., 2012; Van Vliet et al., 2013; Gebre et al., 2014). 
A further increase of the river water temperature has been predicted (Van Vliet et al., 2013). A global increase of the mean and maximum water temperature by $0.8-1.6{ }^{\circ} \mathrm{C}$ and 1.0-2.2 ${ }^{\circ} \mathrm{C}$, respectively, is forecast based on the future emission scenarios B1 and A2 for the time period 20712100 in comparison to the time period 1971-2000. The largest increase of the water temperature is forecast in the United States of America, in Europe, in Eastern China, in Southern Africa, and also in Australia, as a decrease of the river flow is also forecast for these regions. These regions could eventually face deterioration of water quality, which would restrict the availability of water for human needs, for example, the availability of potable water, and also the capacities of hydro power plants would decrease.

Systematic measurements of the water temperature in Latvia were started in 1932 (Stakle and Kanaviňš, 1941). In the beginning of the 1960s, Glazacheva (Glazacheva, 1964; 1965) carried out studies on the seasonal and daily change in water temperature of Latvian rivers, and rivers were classified based on their thermal regime. By continuing the studies carried out in 1964 and 1965, in 1967 Glazacheva (1967) supplemented the study by classification of the rivers of the Latvian SSR in types depending on their thermal regime (102 rivers with an observation period from 1946 to 1962 were used in this study). The thermal regime was singled out as one of the elements of the hydrological regime. Not only were the seasonal changes of the meteorological conditions evaluated, but also the impact of water temperature on physical, chemical, and biological hydrological processes, including on ice conditions (Glazacheva, 1967). Glazacheva in her study (Glazacheva, 1967) classified Latvian rivers marking three main types (cold rivers where the long-term mean water temperature in July was within the range of $12-15{ }^{\circ} \mathrm{C}$, medium cold rivers where the temperature was within the range of $18.5-20{ }^{\circ} \mathrm{C}$, and warm rivers where the water temperature was $20^{\circ} \mathrm{C}$ ). No research of the change in the river water temperature has been recently carried out in Latvia.

The goal of the study was to evaluate the long-term change in the monthly mean water temperature of the upper waters of Latvian rivers (from May to October) and annual maximum water temperature in the time period from 1945 to 2000 .

\section{MATERIALS AND METHODS}

Long-term data on water temperature of Latvian rivers from 19 hydrological monitoring stations (HMS) located on the largest rivers in Latvia and from 17 HMS located on medium and small rivers (Fig. 1) were summarised. Data on air temperature were taken from 13 meteorological monitoring stations (MMS) - Ainaži, Alūksne, Bauska, Daugavpils, Gulbene, Jelgava, Liepāja, Stende, Priekuḷi, Rēzekne, Rūjiena, Zīlāni, and Rịga (Fig. 1). The data were obtained from the Latvian Environment, Geology, and Meteorology Centre.

The analysis of the long-term thermal regime change was performed for the time period 1945-2000 by analysing the monthly mean temperature of upper waters of the Latvian rivers (from May to October) and the annual maximum water temperature.

The mean temperature for decadal periods of each month was calculated from measurements carried out twice daily (at 08:00 and at 20:00 hours). Some periods were 8, or 11 days).

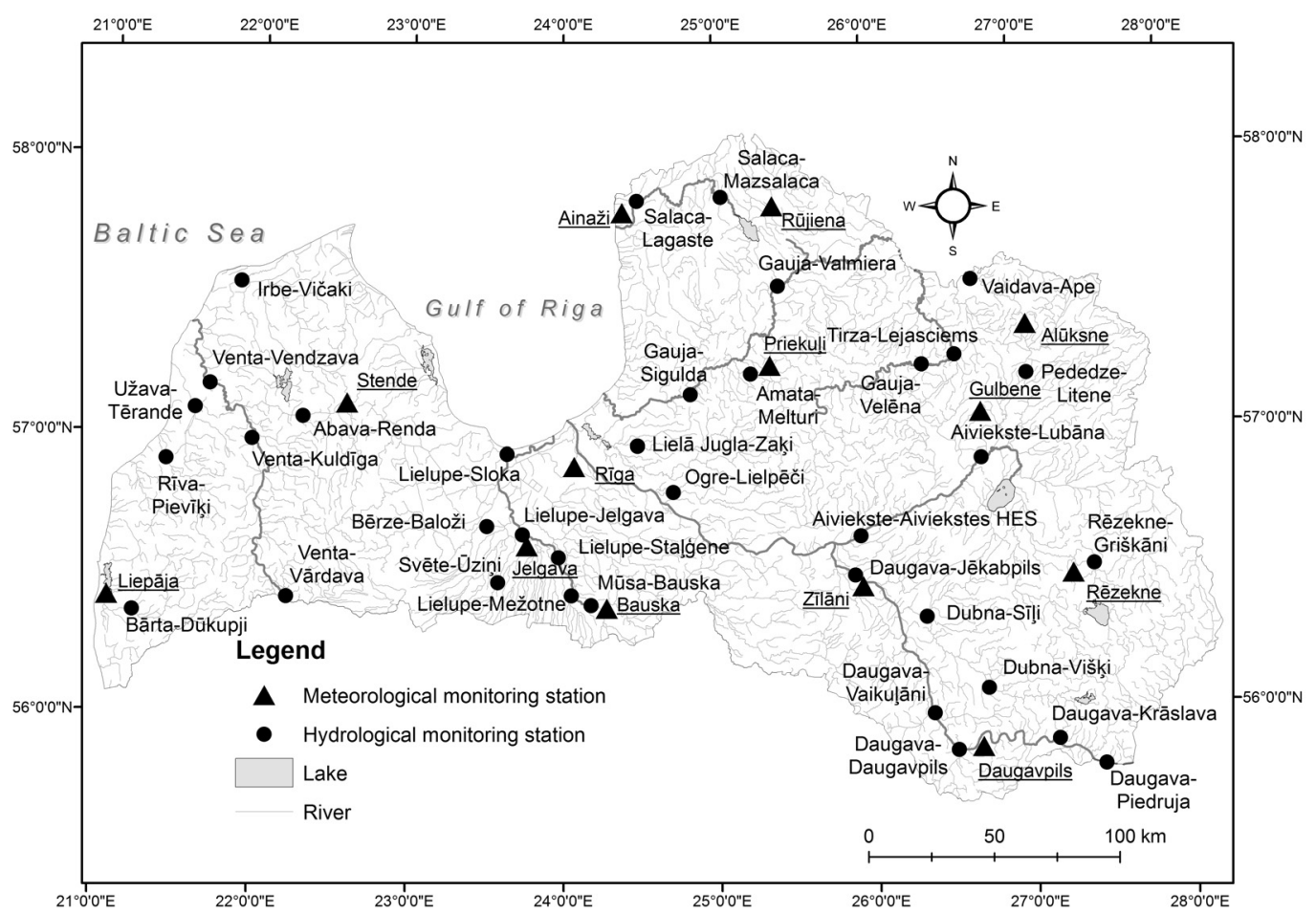

Fig. 1. Location of hydrological monitoring stations and meteorological monitoring stations, Latvia. 
Pearson correlation analysis was performed to test the relationship between water temperature and air temperature. The Mann-Kendall test was applied to evaluate whether the water temperature changes displayed a trend. The MannKendall test was specifically developed for the study of trends of change of climate parameters. The test can be used also when there are missing values and non-typical (very low or very high) values. The Mann-Kendall test is based on the principle of ranges or pairs for comparing two values of observations. The test can also be applied for data series with a seasonal character, as it allows to assessing the test values for each individual month. The test was applied separately for each variable at each site, at a significance level of $p<0.05$. The trend was considered statistically significant at the $5 \%$ level, if the test statistic was above 1.96 or below -1.96. (Hirsch and Slack, 1984; Libiseller and Grimvall, 2002). Thus, Mann-Kendall test not only allows to identify whether the character of the variability of an index is increasing or decreasing, it also allows to evaluate the statistical significance of the trend.

\section{RESULTS}

Long-term changes of the mean water temperature of the warm season. The dynamics of mean water temperature (from May to October), for example, in the Amata, Rēzekne, and Mūsa rivers, were similar (Fig. 2). The lowest mean water temperature over the long-term period in the Amata and Rēzekne rivers was recorded in 1976 (10.2 and 13.2 ${ }^{\circ} \mathrm{C}$, respectively), and in the Mūsa, in 1952 (14.1 $\left.{ }^{\circ} \mathrm{C}\right)$. In 1976, the second lowest mean water temperature was recorded in the Mūsa $\left(14.3{ }^{\circ} \mathrm{C}\right)$. The highest mean water temperature in the Amata was $12.7^{\circ} \mathrm{C}$ in 1967. In the Rēzekne the highest mean temperature $\left(16.3{ }^{\circ} \mathrm{C}\right)$ was recorded in 1967, and in the Mūsa the highest mean temperature $\left(17.2{ }^{\circ} \mathrm{C}\right)$ was recorded in year 1999. Similar patterns were observed in other rivers of Latvia.

The results of the study demonstrated that the long-term mean water temperature was higher in large rivers (Table 1). The highest long-term mean water temperature was recorded in the Lielupe River in the section Mežotne-Sloka, where it was $15.4-16.1{ }^{\circ} \mathrm{C}$, respectively. In the Daugava River, in the section from Piedruja to Jēkabpils, the longterm mean water temperature was within the range 15.3$15.5^{\circ} \mathrm{C}$, and it was slightly lower in the Venta River in the section Vārdava-Vendzava $\left(15.1-15.4{ }^{\circ} \mathrm{C}\right)$ an in the Salaca river from Mazsalaca to Lagaste $\left(15.0-14.7{ }^{\circ} \mathrm{C}\right.$, respectively). The lowest long-term mean water temperature occurred in the Gauja River in the section from Velēna to Sigulda, where it was within the range $13.6-14.2{ }^{\circ} \mathrm{C}$.

The long-term mean water temperature in basins of small and medium rivers of Latvia was highest in small rivers, such as the Mūsa, Svēte, and Bērze of the Lielupe basin $\left(14.3-15.7{ }^{\circ} \mathrm{C}\right)$ (Table 1). The long-term mean water temperature was higher than $15.0{ }^{\circ} \mathrm{C}$ in the Dubna. In other small rivers of the Daugava basin (Pededze, Rēzekne, Ogre, and Lielā Jugla), the long-term mean water temperature is within the range $13.5-14.8{ }^{\circ} \mathrm{C}$. Similar results were obtained in small rivers of the Baltic Sea coastal area and in the Abava. The lowest long-term mean water temperature occurred in small rivers of the Gauja basin, in particular, in the Tirza, Vaidava, and Amata, where it was as low as $11.5-13.1{ }^{\circ} \mathrm{C}$.

Regarding the long-term mean water temperature, most of the large rivers were warmer than the small and medium rivers. Moreover, in cases when there were several HMS on the river, the water temperature was slightly lower at the upper reaches of rivers than in lower reaches.

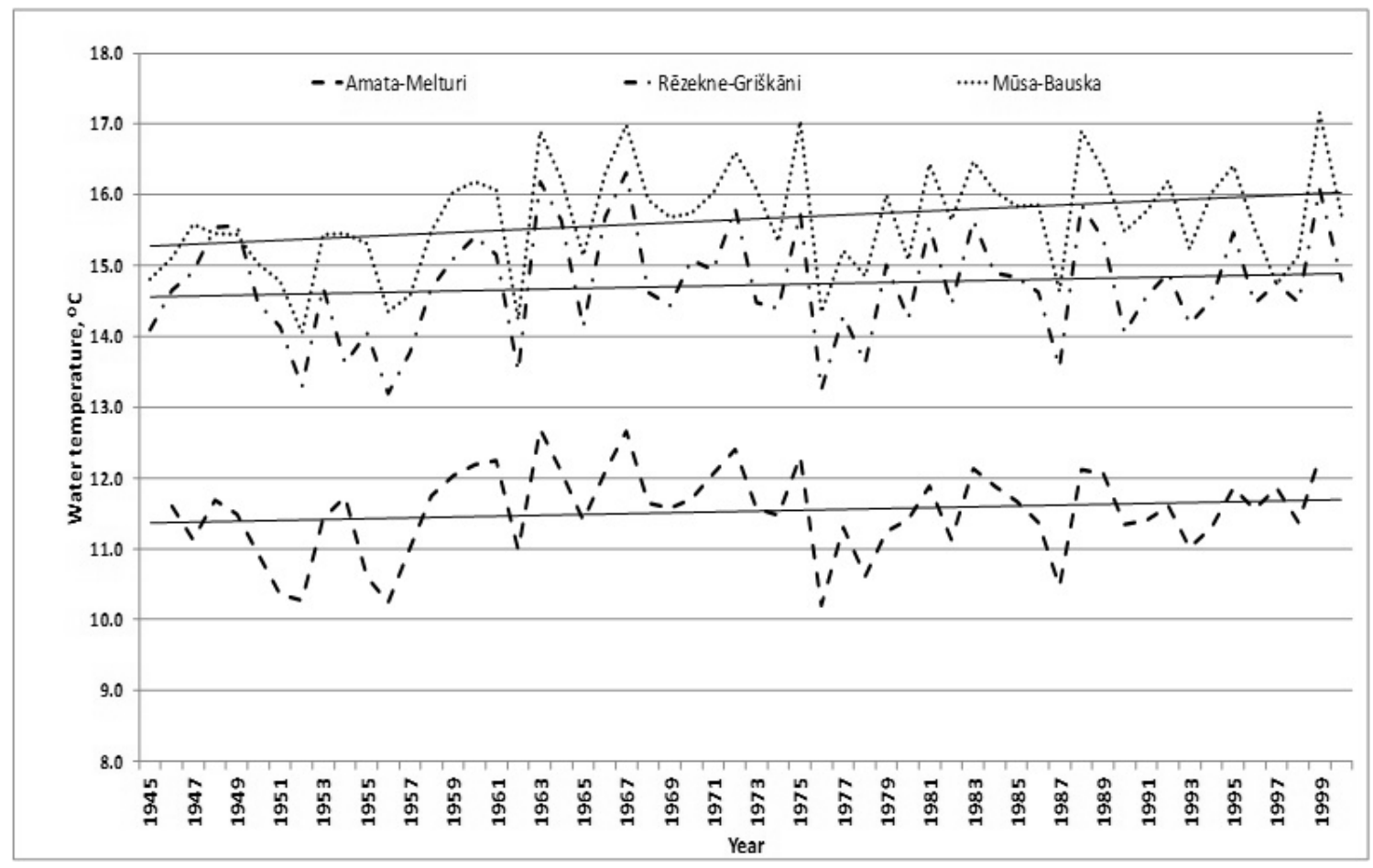

Fig. 2. Long-term changes in mean water temperature during the period from 1945 to 2000 . 
LONG-TERM MEAN WATER TEMPERATURE OVER THE STUDY PERIOD FROM 1945 TO 2000

\begin{tabular}{lcc|c|c}
\hline \multicolumn{1}{c}{ HMS } & Period & Mean & Min & Max \\
\hline Daugava-Piedruja & $1945-2000$ & 15.4 & 13.8 & 17.2 \\
Daugava-Krāslava & $1945-1999$ & 15.5 & 13.8 & 17.8 \\
Daugava-Daugavpils & $1945-2000$ & 15.3 & 13.7 & 17.1 \\
Daugava-Vaikuḷāni & $1946-2000$ & 15.4 & 13.9 & 17.0 \\
Daugava-Jēkabpils & $1945-2000$ & 15.4 & 13.7 & 17.3 \\
Aiviekste-Lubāna & $1945-2000$ & 14.7 & 12.5 & 17.1 \\
Aiviekste-Aiviekstes HES & $1952-2000$ & 14.9 & 13.2 & 16.3 \\
Gauja-Valmiera & $1945-2000$ & 14.2 & 12.6 & 15.7 \\
Gauja-Sigulda & $1945-2000$ & 13.9 & 12.3 & 15.0 \\
Gauja-Velēna & $1958-2000$ & 13.6 & 12.1 & 15.1 \\
Salaca-Lagaste & $1945-2000$ & 14.7 & 13.1 & 15.9 \\
Salaca-Mazsalaca & $1951-2000$ & 15.0 & 13.4 & 16.5 \\
Lielupe-Mežotne & $1945-2000$ & 15.4 & 13.7 & 17.2 \\
Lielupe-Staḷğene & $1945-1999$ & 15.7 & 13.9 & 17.2 \\
Lielupe-Jelgava & $1945-2000$ & 16.1 & 13.9 & 17.9 \\
Lielupe-Sloka & $1945-2000$ & 15.7 & 14.1 & 17.2 \\
Venta-Vārdava & $1946-2000$ & 15.4 & 14.0 & 17.1 \\
Venta-Kuldīga & $1948-2000$ & 15.1 & 13.5 & 16.4 \\
Venta-Vendzava & $1949-2000$ & 15.2 & 13.8 & 16.9
\end{tabular}

Similar trends can also be seen regarding the long-term mean minimum water temperature. A higher long-term mean minimum water temperature occurred in large rivers, and it was slightly lower in small rivers (Table 1). In the Lielupe, the Venta, and the Daugava mean minimum water temperature was within the range $13.5-14.1{ }^{\circ} \mathrm{C}$. In the Salaca it was approximately $13.0{ }^{\circ} \mathrm{C}$, and in the Gauja $13.0{ }^{\circ} \mathrm{C}$. In the group of the medium and small rivers, the highest long-term minimum water temperature was in the Mūsa $\left(14.1{ }^{\circ} \mathrm{C}\right)$, followed by the Dubna $\left(13.6-13.7^{\circ} \mathrm{C}\right)$. In the other small rivers the long-term mean minimum water temperature was about $13.0{ }^{\circ} \mathrm{C}$ or below.

\begin{tabular}{lcc|c|c}
\hline \multicolumn{1}{c}{ HMS } & Period & Mean & Min & Max \\
\hline Dubna-Višḳi & $1945-2000$ & 15.5 & 13.7 & 17.1 \\
Dubna-Sīli & $1945-2000$ & 15.1 & 13.6 & 16.6 \\
Pededze-Litene & $1960-2000$ & 13.5 & 11.5 & 15.7 \\
Rēzekne-Griškāni & $1945-2000$ & 14.7 & 13.2 & 16.3 \\
Ogre-Lielpēči & $1945-2000$ & 14.8 & 11.3 & 16.4 \\
Lielā Jugla-Zaķi & $1945-2000$ & 14.2 & 12.5 & 15.9 \\
Tirza-Lejasciems & $1946-2000$ & 13.1 & 11.3 & 14.8 \\
Vaidava-Ape & $1951-2000$ & 12.0 & 10.6 & 15.1 \\
Amata-Melturi & $1946-1999$ & 11.5 & 10.2 & 12.7 \\
Mūsa-Bauska & $1945-2000$ & 15.7 & 14.1 & 17.2 \\
Svēte-Ūziņi & $1948-2000$ & 14.3 & 12.2 & 15.6 \\
Bērze-Baloži & $1961-2000$ & 14.3 & 13.0 & 15.8 \\
Abava-Renda & $1964-2000$ & 14.2 & 12.1 & 15.4 \\
Irbe-Vičaki & $1946-2000$ & 14.1 & 12.5 & 15.6 \\
Užava-Tērande & $1947-2000$ & 13.6 & 12.1 & 15.3 \\
Rīva-Pievīḳi & $1963-2000$ & 13.8 & 12.3 & 15.2 \\
Bārta-Dūkupji & $1949-2000$ & 14.8 & 13.2 & 16.2
\end{tabular}

The long-term mean maximum water temperature in most rivers was within the range around $15.0-17.0{ }^{\circ} \mathrm{C}$ (Table 1).

Mann-Kendall test demonstrated that during the monitoring period from May to October, the mean water temperature was mainly characterised by a positive trend (Fig. 3) (in $72.2 \%$ of rivers). Moreover, in $22.2 \%$ of the rivers the trend was statistically significant at $p<0.05$ (Table 2). A statistically significant trend was observed in large rivers, i.e. in the Daugava - at Piedruja, Daugavpils, and Jēkabpils HMS, in the Salaca - at Mazsalaca HMS, in the Lielupe at Mežotne and Sloka HMS, and in the Mūsa - Bauska and

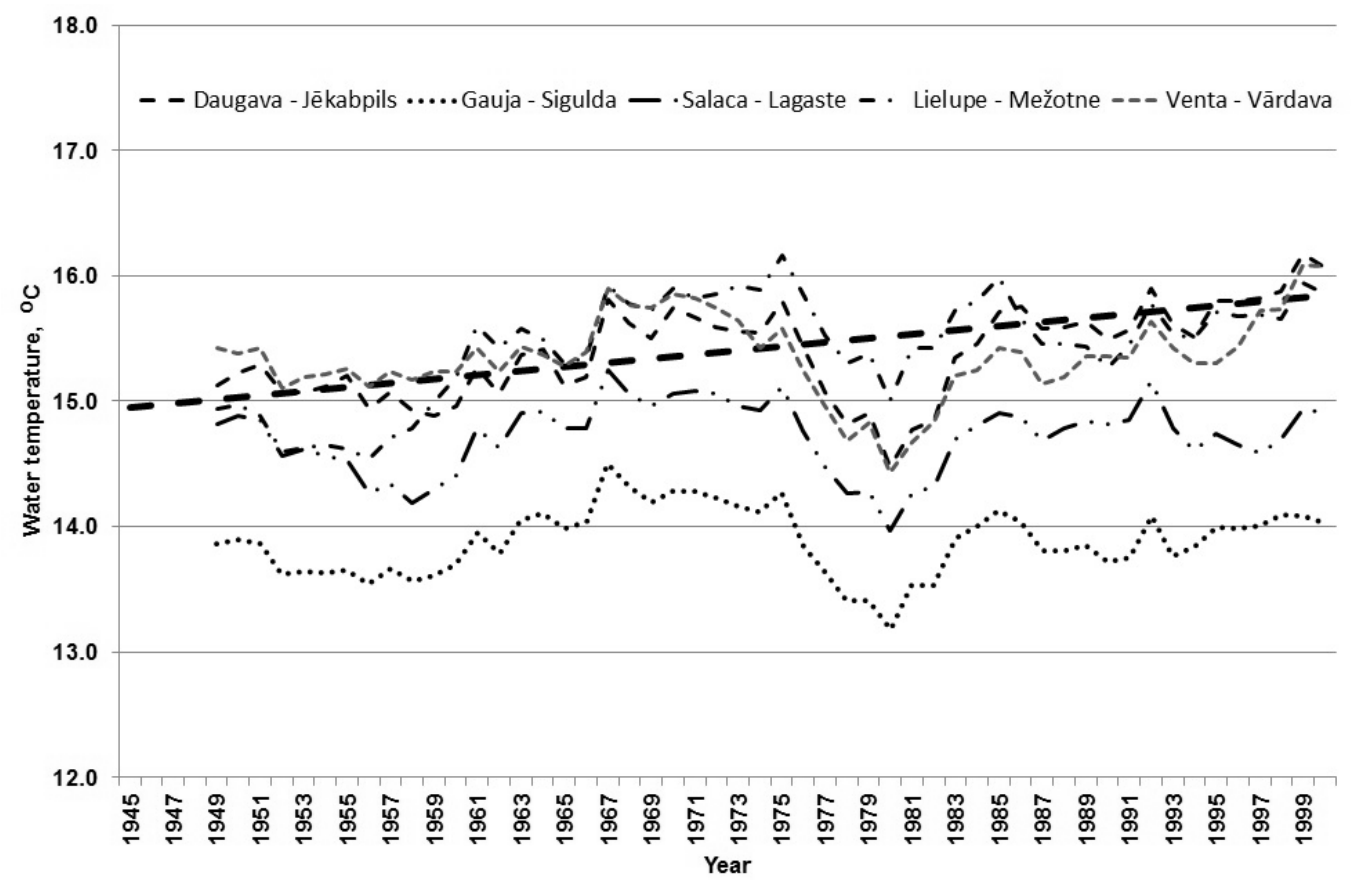

Fig. 3. Trends of the mean water temperature (May - October) in the period from 1945 to 2000 on the basis of the example of the big rivers of Latvia. The curves are smoothed with a 5-year moving average. Interrupted line shows the changeability trend. 
rivers within the range from $20.1{ }^{\circ} \mathrm{C}$ at Vaidava - Ape HMS

MANN-KENDALL TEST RESULTS FOR THE LONG-TERM MEAN AND MAXIMUM WATER TEMPERATURE

\begin{tabular}{|c|c|c|c|c|}
\hline \multirow[t]{2}{*}{ HMS } & \multicolumn{2}{|c|}{ Mean temperature } & \multicolumn{2}{|c|}{ Maximum temperature } \\
\hline & MK-Stat & $p$-value & MK-Stat & $p$-value \\
\hline Daugava-Piedruja & 2.33 & 0.02 & -0.87 & 0.38 \\
\hline Daugava-Krāslava & 1.25 & 0.21 & -0.65 & 0.52 \\
\hline Daugava-Daugavpils & 1.97 & 0.05 & 0.52 & 0.61 \\
\hline Daugava-Vaikuḷāni & 1.83 & 0.07 & -1.12 & 0.26 \\
\hline Daugava-Jēkabpils & 2.50 & 0.01 & 0.18 & 0.86 \\
\hline Aiviekste-Lubāna & -0.19 & 0.85 & -3.29 & 0.00 \\
\hline Aiviekste-Aiviekstes HES & -1.09 & 0.27 & -3.32 & 0.00 \\
\hline Gauja-Valmiera & 0.59 & 0.56 & -2.16 & 0.03 \\
\hline Gauja-Sigulda & 0.98 & 0.33 & -2.48 & 0.01 \\
\hline Gauja-Velēna & -1.20 & 0.23 & -2.74 & 0.01 \\
\hline Salaca-Lagaste & 0.65 & 0.52 & -1.25 & 0.21 \\
\hline Salaca-Mazsalaca & 2.86 & 0.00 & -1.31 & 0.19 \\
\hline Lielupe-Mežotne & 2.64 & 0.01 & -3.15 & 0.00 \\
\hline Lielupe-Stalǵ̣gene & 0.98 & 0.33 & -1.87 & 0.06 \\
\hline Lielupe-Jelgava & 1.79 & 0.07 & 0.42 & 0.68 \\
\hline Lielupe-Sloka & 2.17 & 0.03 & -1.33 & 0.18 \\
\hline Venta-Vārdava & 0.68 & 0.50 & -1.96 & 0.05 \\
\hline Venta-Kuldīga & 1.35 & 0.18 & -2.66 & 0.01 \\
\hline Venta-Vendzava & 1.72 & 0.09 & -0.17 & 0.87 \\
\hline Dubna-Višķi & 3.19 & 0.00 & 0.15 & 0.88 \\
\hline Dubna-Sīli & 0.25 & 0.80 & -2.80 & 0.01 \\
\hline Pededze-Litene & -2.63 & 0.01 & -3.79 & 0.00 \\
\hline Rēzekne-Griškāni & 0.81 & 0.42 & -2.42 & 0.02 \\
\hline Ogre-Lielpēči & 1.70 & 0.09 & -3.09 & 0.00 \\
\hline Lielā Jugla-Zaḳi & 0.76 & 0.45 & -2.78 & 0.01 \\
\hline Tirza-Lejasciems & -0.79 & 0.43 & -5.53 & 0.00 \\
\hline Vaidava-Ape & -3.04 & 0.00 & -4.36 & 0.00 \\
\hline Amata-Melturi & 0.63 & 0.53 & -4.64 & 0.00 \\
\hline Mūsa-Bauska & 2.16 & 0.03 & -0.49 & 0.63 \\
\hline Svēte-Ūziņi & 0.85 & 0.39 & -3.03 & 0.00 \\
\hline Bērze-Baloži & -0.76 & 0.45 & -2.17 & 0.03 \\
\hline Abava-Renda & -0.94 & 0.35 & 0.15 & 0.88 \\
\hline Irbe-Vičaki & 0.38 & 0.71 & -2.54 & 0.01 \\
\hline Užava-Tērande & 0.06 & 0.95 & -3.32 & 0.00 \\
\hline Rīva-Pievīk,i & -2.20 & 0.03 & -2.78 & 0.01 \\
\hline Bārta-Dūkupji & -1.38 & 0.17 & -2.57 & 0.01 \\
\hline
\end{tabular}

Dubna - Višķi HMS. A statistically significant negative trend also occurred for mean water temperature, i.e. in $8.3 \%$ of rivers (at the Pededze - Litene HMS, Vaidava - Ape and Rīva - Pievīki HMS). A negative trend was observed in $19.4 \%$ of the rivers showing decreasing mean water temperature. A negative trend also occurred in the Aiviekste River, in the upper reach of the Gauja at Velēna, and in the Tirza at Lejasciems HMS, as well as in the Bērze at Baloži, in the Abava at Renda, and in the Bārta at Dūkupji HMS.

Changes in the annual maximum water temperature. The long-term mean maximum water temperature in large rivers was within the range from $22.7^{\circ} \mathrm{C}$ at Gauja - Velēna HMS to $25.7{ }^{\circ} \mathrm{C}$ at Lielupe - Mežotne HMS, and in small to $25.8{ }^{\circ} \mathrm{C}$ at Mūsa - Bauska HMS (Table 3). There was no significant difference between the large and small rivers regarding the lowest long-term maximum water temperature, which was in the range $18.7-22.4{ }^{\circ} \mathrm{C}$, except in small rivers of the Gauja basin where it was within the range 16.7-17.4 ${ }^{\mathrm{O}} \mathrm{C}$.

The highest long-term maximum water temperature occurred in the Lielupe in the section Mežotne - Jelgava (29.0-29.8 ${ }^{\circ} \mathrm{C}$, respectively) (Table 3 ). The long-term maximum water temperature was within the range $26.2-27.8{ }^{\circ} \mathrm{C}$ in the Daugava in the section Piedruja - Jekkabpils, and the temperature was slightly lower in the Venta in the section Vārdava - Vendzava $\left(25.8-27.4{ }^{\circ} \mathrm{C}\right)$, in the Salaca (26.4$26.8{ }^{\circ} \mathrm{C}$ ), and in the Gauja in the section Velēna - Sigulda $\left(25.2-26.0^{\circ} \mathrm{C}\right)$. In small and medium rivers, the long-term maximum water temperature was higher in small rivers of the Daugava basin $\left(26.4-28.5^{\circ} \mathrm{C}\right)$ and in the small rivers of the Lielupe basin $\left(24.8-28.8{ }^{\circ} \mathrm{C}\right)$. A long-term maximum water temperature within the range $25.2-26.7{ }^{\circ} \mathrm{C}$ was observed in small rivers of the Gauja basin and in the small rivers of the Baltic Sea coastal area.

The long-term change in the annual maximum water temperature showed a significant negative trend (Fig. 4) (in $61.1 \%$ of rivers the trend was statistically significant at $p<$ 0.05 ), and in $25 \%$ of the rivers a negative trend was obtained (Table 2). A statistically significant decrease of maximum water temperature occurred in the Gauja in the section Velēna - Sigulda and in the Aiviekste in the section Lubāna - Aiviekste HPP, in the Lielupe at Mežotne and in the Venta in the section Vārdava - Kuldīga. For small and medium rivers a significant negative trend occurred in small rivers of the Daugava and Gauja basins, in small rivers of the Baltic Sea coastal area and small rivers of the Lielupe basin (Svēte and Bērze).

The highest temperature usually occurred in the middle of summer, in July. Among the large rivers, the highest water temperature occurred in $50 \%$ of years in July in the Gauja in the section Velēna - Sigulda, in the Aiviekste at Aiviekste HPP HMS, and in the Venta in the section Kuldiga - Vendzava (Table 4). In the other large rivers the highest water temperature occurred in July in 39.3-48.2\% of years. In approximately $30-40 \%$ of years in the large rivers the highest water temperature occurred in June, and in $12.5-26.8 \%$ of years, in August. In some years (1.8\%), the highest water temperature in the Lielupe occurred as early as in May or as late as in September.

Similarly to the large rivers, also in the medium and small rivers, the highest water temperature occurred most often in July (Table 4). In $50 \%$ of years the highest temperature occurred in July in small rivers of the Daugava basin (in the Dubna at Viški HMS, in the Pededze at Litene HMS, in the Ogre at Lielpeči HMS), and the Gauja basin (in the Tirza at Lejasciems HMS and in the Amata at Melturi HMS). In the other medium and small rivers the highest water temperature occurred in July in $36.7-49.1 \%$ of years. In some 
LONG-TERM MAXIMUM WATER TEMPERATURE OVER THE STUDY PERIOD FROM 1945 TO 2000

\begin{tabular}{lccccc}
\hline \multicolumn{1}{c|}{ HMS } & Periods & Mean & Min & Max \\
\hline Daugava-Piedruja & $1945-2000$ & 24.6 & 20.2 & 27.8 \\
Daugava-Krāslava & $1945-1999$ & 23.9 & 19.8 & 26.2 \\
Daugava-Daugavpils & $1945-2000$ & 24.3 & 20.1 & 26.2 \\
Daugava-Vaikuḷāni & $1946-2000$ & 24.2 & 20.0 & 26.3 \\
Daugava-Jēkabpils & $1945-2000$ & 23.8 & 19.6 & 26.8 \\
Aiviekste-Lubāna & $1945-2000$ & 24.1 & 21.0 & 27.6 \\
Aiviekste-Aiviekstes HES & $1952-2000$ & 24.1 & 20.8 & 27.5 \\
Gauja-Valmiera & $1945-2000$ & 23.4 & 20.0 & 26.0 \\
Gauja-Sigulda & $1945-2000$ & 22.9 & 19.7 & 25.6 \\
Gauja-Velēna & $1958-2000$ & 22.7 & 20.2 & 25.2 \\
Salaca-Lagaste & $1945-2000$ & 23.5 & 20.8 & 26.4 \\
Salaca-Mazsalaca & $1951-2000$ & 24.2 & 21.0 & 26.8 \\
Lielupe-Mežotne & $1945-2000$ & 25.7 & 22.4 & 29.6 \\
Lielupe-Staļǵene & $1945-1999$ & 25.1 & 22.0 & 29.8 \\
Lielupe-Jelgava & $1945-2000$ & 24.7 & 20.8 & 29.0 \\
Lielupe-Sloka & $1945-2000$ & 23.5 & 20.0 & 25.7 \\
Venta-Vārdava & $1946-2000$ & 23.9 & 21.0 & 26.9 \\
Venta-Kuldīga & $1948-2000$ & 24.6 & 21.1 & 27.4 \\
Venta-Vendzava & $1949-2000$ & 23.5 & 20.9 & 25.8
\end{tabular}

\begin{tabular}{lccccc}
\hline \multicolumn{1}{c}{ HMS } & Periods & Mean & Min & Max \\
\hline Dubna-Višķi & $1945-2000$ & 25.3 & 22.0 & 28.2 \\
Dubna-Sīḷi & $1945-2000$ & 23.8 & 21.1 & 26.4 \\
Pededze-Litene & $1960-2000$ & 22.1 & 19.4 & 24.8 \\
Rēzekne-Griškāni & $1945-2000$ & 24.5 & 21.1 & 28.4 \\
Ogre-Lielpēči & $1945-2000$ & 25.0 & 21.2 & 27.8 \\
Lielā Jugla-Zaķi & $1945-2000$ & 25.0 & 21.1 & 28.5 \\
Tirza-Lejasciems & $1946-2000$ & 22.0 & 17.2 & 26.4 \\
Vaidava-Ape & $1951-2000$ & 20.1 & 16.7 & 25.0 \\
Amata-Melturi & $1946-1999$ & 20.8 & 17.4 & 25.2 \\
Mūsa-Bauska & $1945-2000$ & 25.8 & 22.6 & 28.8 \\
Svēte-Ūziṇi & $1948-2000$ & 22.7 & 19.6 & 26.3 \\
Bērze-Baloži & $1961-2000$ & 22.0 & 19.2 & 24.8 \\
Abava-Renda & $1964-2000$ & 22.2 & 19.8 & 26.7 \\
Irbe-Vičaki & $1946-2000$ & 22.9 & 19.6 & 25.2 \\
Užava-Tērande & $1947-2000$ & 22.6 & 18.7 & 25.3 \\
Rīva-Pievīki & $1963-2000$ & 22.9 & 20.4 & 25.4 \\
Bārta-Dūkupji & $1949-2000$ & 23.3 & 19.8 & 25.7 \\
& & & &
\end{tabular}

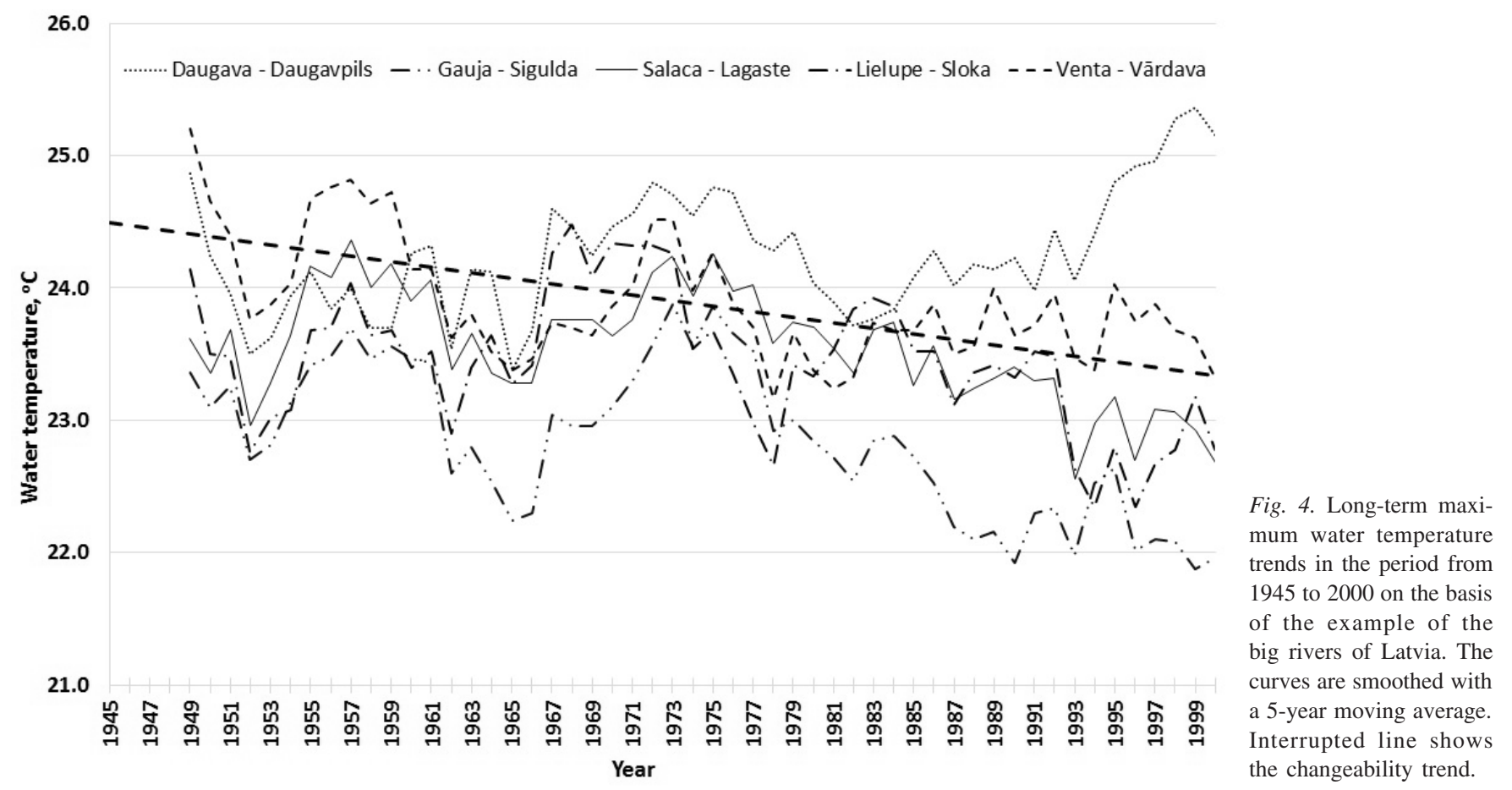

rivers, for example, in the Vaidava at Ape HMS, the highest water temperature occurred as early as in June. However, in the Mūsa at Bauska HMS, in the Lielā Jugla at Zaķi HMS, in the Užava at Tērande HMS, and in the Bārta at Dūkupju HMS, the number of observations of highest water temperature in June and July was similar. The highest water temperature occurred in August in 8.9-21.8\% of years. The maximum temperature was rarely observed in August in the Lielā Jugla at Zaki HMS and well in Tirza at Lejasciema HMS (\% of the years). The maximum temperature occurred most often in August in the Irbe at Vičaki HMS (20\% of years). In small and medium rivers, compared to large rivers, there were more years when the highest water temperature occurred as early as in May.

Correlation between the water temperature and the air temperature. Over the long-term, the correlation between mean air temperature and mean water temperature was positive and statistically significant, i.e. along with a long-term increase of mean air temperature, also the long-term mean 
THE TIME OF RECORDING OF THE MAXIMUM WATER TEMPERATURE (PERCENTAGE DISTRIBUTION)

\begin{tabular}{|c|c|c|c|c|c|c|}
\hline \multirow[t]{2}{*}{ HMS } & \multirow[t]{2}{*}{ Period } & May & June & July & August & September \\
\hline & & \multicolumn{5}{|c|}{$\%$} \\
\hline Daugava-Piedruja & $1945-2000$ & - & 27 & 48 & 25 & - \\
\hline Daugava-Daugavpils & $1945-2000$ & 2 & 32 & 41 & 25 & - \\
\hline Daugava-Vaikuḷāni & 1946-2000 & - & 32 & 48 & 20 & - \\
\hline Daugava-Jēkabpils & $1945-2000$ & - & 32 & 43 & 25 & - \\
\hline Aiviekste-Lubāna & $1945-2000$ & - & 38 & 43 & 20 & - \\
\hline Aiviekste-Aiviekstes HES & $1952-2000$ & - & 21 & 57 & 22 & - \\
\hline Gauja-Valmiera & $1945-2000$ & - & 29 & 52 & 20 & - \\
\hline Gauja-Sigulda & $1945-2000$ & - & 38 & 50 & 13 & - \\
\hline Gauja-Velēna & $1958-2000$ & - & 27 & 61 & 13 & - \\
\hline Salaca-Lagaste & $1945-2000$ & - & 32 & 45 & 23 & - \\
\hline Lielupe-Mežotne & 1945-2000 & 2 & 41 & 39 & 18 & - \\
\hline Lielupe-Staļǵene & 1945-1999 & 2 & 36 & 41 & 20 & 2 \\
\hline Lielupe-Jelgava & 1945-2000 & 2 & 30 & 48 & 20 & - \\
\hline Lielupe-Sloka & 1945-2000 & - & 27 & 46 & 27 & - \\
\hline Venta-Vārdava & 1946-2000 & 2 & 32 & 45 & 21 & - \\
\hline Venta-Kuldīga & 1948-2000 & - & 20 & 57 & 23 & - \\
\hline Venta-Vendzava & 1949-2000 & 2 & 27 & 52 & 20 & - \\
\hline Dubna-Višķi & 1945-2000 & 2 & 29 & 50 & 20 & - \\
\hline Dubna-Sīḷi & $1945-2000$ & - & 39 & 45 & 16 & - \\
\hline Pededze-Litene & 1960-2000 & 2 & 22 & 56 & 20 & - \\
\hline Rēzekne-Griškāni & $1945-2000$ & 2 & 46 & 38 & 14 & - \\
\hline Ogre-Lielpēči & $1945-2000$ & 2 & 30 & 54 & 14 & - \\
\hline Vaidava-Ape & 1951-2000 & 2 & 51 & 37 & 10 & - \\
\hline Amata-Melturi & 1946-1999 & - & 39 & 50 & 11 & - \\
\hline Mūsa-Bauska & 1945-2000 & 2 & 43 & 41 & 14 & - \\
\hline Svēte-Ūziņi & $1948-2000$ & 2 & 39 & 41 & 19 & - \\
\hline Bērze-Baloži & 1961-2000 & 3 & 38 & 41 & 18 & - \\
\hline Abava-Renda & 1964-2000 & 3 & 36 & 44 & 17 & - \\
\hline Irbe-Vičaki & 1946-2000 & - & 29 & 49 & 22 & - \\
\hline Užava-Tērande & $1947-2000$ & 4 & 37 & 39 & 20 & - \\
\hline Rīva-Pievīḳi & 1963-2000 & 3 & 46 & 38 & 13 & - \\
\hline Bārta-Dūkupji & 1949-2000 & 2 & 41 & 41 & 16 & - \\
\hline
\end{tabular}

water temperature in rivers has increased (Table 5). Longterm maximum water temperature was not significantly correlated with air temperature.

\section{DISCUSSION}

The thermal regime of rivers depends on the climate, mainly solar radiation (this is why the changes in the water temperature along the year follow the pattern of change in the air temperature) and also on the form of water collection of the river. Groundwater inflows have a particularly large impact. In winter the water temperature in most of the rivers decreases to $0{ }^{\circ} \mathrm{C}$. In the middle of the summer considerable contrast of water temperature can be seen. For example, in
July in various Latvian rivers the long-term difference of water temperatures can be as high as $8.0-9.0{ }^{\circ} \mathrm{C}$ (Glazačeva, 1975). Not only the climate, but also the terrain, the geological structure of the river basin, and the hydrology play important roles in the thermal regime of rivers (Glazacheva, 1967).

The mean water temperature over the period from May to October was higher in large rivers of Latvia than in the medium and small rivers. Glazacheva (1980) found that in the warm season the water was warmest in the Daugava River and its tributaries, Aiviekste and Dubna, and in the Venta, Lielupe, Mēmele, and Mūsa, and in many small rivers of lowlands where river beds are shallow and where there is little inflow of underground waters. In Lithuania the water 
(12.0-13.5 $\left.{ }^{\circ} \mathrm{C}\right)$. Also in Lithuania, rivers flowing from upCORRELATION BETWEEN WATER AND AIR TEMPERATURE

\begin{tabular}{|c|c|c|}
\hline HMS & $\begin{array}{c}\text { Correlation coefficient } \\
\text { for long-term max } \\
\text { temperature }\end{array}$ & $\begin{array}{c}\text { Correlation coefficien } \\
\text { for long-term mean } \\
\text { temperature }\end{array}$ \\
\hline Daugava-Piedruja & 0.074 & $0.517^{* *}$ \\
\hline Daugava-Daugavpils & 0.202 & $0.455^{* *}$ \\
\hline Daugava-Jēkabpils & 0.107 & $0.579 * *$ \\
\hline Daugava-Krāslava & 0.126 & $0.541^{* *}$ \\
\hline Daugava-Vaikuḷāni & 0.135 & $0.599 * *$ \\
\hline Dubna-Sịḷi & -0.034 & $0.486^{* *}$ \\
\hline Aiviekste-Lubāna & -0.141 & $0.354 * *$ \\
\hline $\begin{array}{l}\text { Aiviekste-Aiviekstes } \\
\text { HES }\end{array}$ & -0.084 & $0.419^{* *}$ \\
\hline Rēzekne-Griškāni & 0.017 & $0.496^{* * *}$ \\
\hline Pededze-Litene & -0.078 & 0.329 \\
\hline Ogre-Lielpēči & 0.145 & $0.457 * *$ \\
\hline Lielā Jugla-Zaḳi & 0.127 & 0.333 \\
\hline Gauja-Velēna & -0.038 & $0.312^{*}$ \\
\hline Gauja-Valmiera & 0.075 & $0.468^{* * *}$ \\
\hline Gauja-Sigulda & 0.005 & $0.494^{* *}$ \\
\hline Amata-Melturi & -0.011 & $0.488^{* *}$ \\
\hline Vaidava-Ape & -0.124 & 0.152 \\
\hline Tirza-Lejasciems & -0.117 & $0.391^{* *}$ \\
\hline Lielupe-Mežotne & 0.058 & $0.493^{* *}$ \\
\hline Lielupe-Jelgava & 0.137 & $0.517^{* *}$ \\
\hline Lielupe-Sloka & -0.003 & $0.476^{* *}$ \\
\hline Lielupe-Staļgene & 0.051 & $0.612^{* *}$ \\
\hline Svēte-Ūziņi & -0.001 & $0.446 * *$ \\
\hline Mūsa-Bauska & 0.070 & $0.463^{* *}$ \\
\hline Bērze-Baloži & 0.104 & $0.421^{* *}$ \\
\hline Salaca-Lagaste & 0.049 & $0.539 * *$ \\
\hline Salaca-Mazsalaca & 0.056 & $0.598^{* *}$ \\
\hline Venta-Vārdava & 0.084 & $0.462 * *$ \\
\hline Venta-Kuldīga & 0.075 & $0.500^{* *}$ \\
\hline Venta-Vendzava & 0.170 & $0.632 * *$ \\
\hline Abava-Renda & $0.377^{*}$ & 0.303 \\
\hline Irbe-Vičaki & -0.003 & $0.509 * *$ \\
\hline Užava-Tērande & 0.016 & $0.431^{* *}$ \\
\hline Rīva-Pievīḳi & 0.002 & $0.341 * *$ \\
\hline Bārta-Dūkupji & 0.134 & $0.379 * *$ \\
\hline
\end{tabular}

** statistically significant at $p<0.01 ; *$ statistically significant at $p<0.05$

temperature was observed to be generally higher in large rivers compared to the small ones (Jurgelènaitè et al., 2012). In Latvia, the mean water temperature in large rivers varied over the long term within the range of $14.7-16.1{ }^{\circ} \mathrm{C}$, while in Lithuania the range was slightly higher (15.0-16.2 ${ }^{\circ} \mathrm{C}$ ) (Jurgelènaitè et al., 2012). In medium and small rivers of eastern and central Latvia the mean water temperature was higher over the long term $\left(14.2-15.7{ }^{\circ} \mathrm{C}\right)$ than in rivers of western Latvia that flowed from the West slopes of Western Kursa Upland $\left(13.6-13.8{ }^{\circ} \mathrm{C}\right)$ and in the rivers of the western (Amata, etc.) and eastern (Tirza, etc.) slopes of Vidzeme highland $\left(11.5-13.1{ }^{\circ} \mathrm{C}\right)$, and in rivers flowing from the Alūksne Upland (Vaidava, Pededze, etc.) lands (Žemaitija Upland and as well as the western slopes of Augštaitija Upland) had a lower long-term mean water temperature (Jurgelenaite et al., 2012). This was explained by a more sandy catchment basin of a river, where spring snow melting water supplemented groundwater, which later flowed into rivers. Infiltration velocity is much higher in sandy soils, which allows the snow melting water to supplement the groundwater reserves to a greater degree. Also Glazacheva (1967) observed that rivers flowing from highlands had colder water due to groundwater inflow into rivers. However, this is only true in cases where groundwater comes from the lowest water carrying layers, as in top and middle water carrying layers the groundwater has a temperature of $7.0-8.0^{\circ} \mathrm{C}$, and thus inflows in rivers and do not considerably affect the river water temperature.

Water temperature was lower in upper reaches of rivers than in lower reaches, particularly in the Lielupe, Gauja and Aiviekste. Jurgelenaite et al. (2012) obtained similar results in Lithuania, and also water temperature in river tributaries was higher in tributaries located further from the upper part of the rivers. In a study carried out by Pekarova et al. (2011) on the Bela River in northern Slovakia, water temperature downstream also increased downstream. As water moves downstream, the friction produces heat energy, and the flow is also supplemented by the water from tributaries (Hammond and Pryce, 2007).

Most of the studies that have been conducted on water temperature were focused on the evaluation of the impact of the climate change, and have found a relationship between water temperature and atmosphere conditions, particularly temperature (Caissie, 2006; Arai, 2009; Prats et al., 2010; Kaushal et al., 2010; Van Vliet et al., 2011). Our study also found significant correlation between mean water and air temperature. The Mann-Kendall test indicated mainly a positive trend for mean water temperature over the time period from May to October, which in $20 \%$ of rivers was statistically significant. In Lithuania, for the time period 19452010 , in 41 HMS in $15 \%$ of the cases a significant increase of water temperature was found (Jurgelenaite et al., 2012). An increase of water temperature in rivers has been observed in many regions globally (Liu et al., 2005; Webb and Nobilis, 2007; Pekarova et al., 2008; Arai, 2009; Kaushal et al., 2010; Prats et al., 2010; Pekarova et al., 2011; Toone et al., 2011; Van Vliet et al., 2011; Dickson et al., 2012; Floury et al., 2012; Garner et al., 2013; Xin and Kinouchi, 2013; Gebre et al., 2014; Orr et al., 2014;). During the $20^{\text {th }}$ century, water temperature in the largest rivers of the United States of America has increased by $0.009-0.07{ }^{\circ} \mathrm{C}$ (Kaushal et al., 2010), and in Canada by $0.02{ }^{\circ} \mathrm{C}$ (Morisson et al., 2002). In southern Europe in the Pyrenean Peninsula, in the Ebro River located in the North East of Spain, an increase of water temperature by $2.3{ }^{\circ} \mathrm{C}$ was observed (1955-2000), which was due not only to climate change, but also due to reduced river discharge, construction of dams, and a nuclear power plant on the banks of the river (Prats et al., 2010). Also, in the longest river in France, the 
Luara, an increase of the water temperature by $\sim 1.2{ }^{\circ} \mathrm{C}$ was observed (1977-2008), and the largest temperature increase occurred during the period from May to August. In England and Wales, Orrs et al. (2014) found an increase of the water temperature by $0.03{ }^{\circ} \mathrm{C}$ (1990-2006). In Slovakia, in the region of Tatri, temperature of water has increased the Donava by $0.6{ }^{\circ} \mathrm{C}$ in the period 1926-2005 (Pekarova et al. 2008 ) and in the Bela river by $0.12{ }^{\circ} \mathrm{C}$ during $1959-2008$ (Pekarova et al., 2011). The increasing temperature trend in rivers of the northern part of Slovakia could not be seen until year 1970 and only occurred during the last 40 years (Pekarova et al. 2008). The major impact of the atmosphere on water temperature can be mostly seen during heat waves and dry periods (Van Vliet et al. 2011), as in the largest rivers in the world in the time period from 1980 to 1999 , it was observed that when the air temperature increased by 2.0 ${ }^{\circ} \mathrm{C}$, the water temperature increased by $1.3{ }^{\circ} \mathrm{C}$, but when air temperature increased by $4.0{ }^{\circ} \mathrm{C}$, the water temperature increased by $2.6{ }^{\circ} \mathrm{C}$, and when air temperature increased by $6.0{ }^{\circ} \mathrm{C}$, the water temperature increased by $3.8{ }^{\circ} \mathrm{C}$. Also, taking into account the decrease of the discharge, it was found that as the air temperature increased by $4.0{ }^{\circ} \mathrm{C}$ and the discharge decreased by $40 \%$ the water temperature could even increase by $6.0{ }^{\circ} \mathrm{C}$ (Van Vliet et al., 2011).

Maximum water temperature in rivers of Latvia mostly occurred in July. In other studies the maximum temperature occurs in summer months (June, July, and August) (Liu et al., 2005; Pekarova et al., 2008). In contrast to mean water temperature, the maximum water temperature tends to decrease over long-term, which might be related to the seasonal change in the solar radiation inflow (Pekarova et al., 2008).

\section{ACKNOWLEDGEMENTS}

We greatly acknowledge the support of the European Social Fund within the project "Support for Doctoral Studies at University of Latvia" and the Latvian Council of Science (grants No. 526/2013 and No. 514/2012) for this research.

\section{REFERENCES}

Arai, T. (2009). Climate change and variations in the water temperature and ice cover of inland waters. Jap. J. Limnol., 70 (2), 99-116.

Caissie, D. (2006). The thermal regime of rivers: Review. Freshwater Biol., 51, 1389-1406.

Carrivick, J. L., Brown, L. E., Hannah, D. M., Turner, A. G. D. (2012). Numerical modelling of spatio-temporal thermal heterogeneity in a complex river system. J. Hydrol., 414 (415), 491-502.

Dickson, N. E, Carrivick, J. L., Brown, L. E. (2012). Flow regulation alters alpine river thermal regimes. J. Hydrol., 464/465, 505-516.

Floury, M., Delattre, C., Ormerod, S. J., Souchon, Y. (2012). Global versus local change effects on a large European river. Sci. Total Environ., 441, 220-229.

Garner, G., Hannah, D. M., Sadler, J. P., Orr, H. G. (2013). River temperature regimes of England and Wales: Spatial patterns, inter-annual variability and climatic sensitivity. Hydrological Processes, 28 (22), 5583-5598.
Gebre, S., Boissy, T., Alfredsen, K. (2014). Sensitivity to climate change of the thermal structure and ice cover regime of three hydropower reservoirs. J. Hydrol., 510, 208-227.

Glazačeva, L. (1975). Virszemes ūden,i [Surface waters]. Grām.: Latvijas PSR geogrāfija [Geography of the Latvian SSR]. Zinātne, Rīga, 74.-90. lpp. (in Latvian).

Glazacheva, L. I. (1964). Ice and thermal regime of rivers and lakes of the Latvian SSR. Abstract of the Candidate of Sciences dissertation [Глазачева, Л. И. Ледовый и термический режим рек и озер Латвийской ССР. Автореферат диссертации на соискание ученой степени кандидата географических науk]. Tartu State University, Tartu, 18 pp. (in Russian).

Glazacheva, L. I. (1965). Ice and thermal regime of rivers and lakes of the Latvian SSR. Scientific notes: Geographical Sciences. Vol. 65 [Глазачева, Л. И. Ледовый и термический режим рек и озер Латвийской CСP. Ученые записки: Географические науки Том 65]. Zvaigzne, Rīga, 181 pp. (in Russian).

Glazacheva, L. I. (1967). Types of rivers by thermal regime in Latvian SSR [Глазачева, Л. И. Типы рек Латвийской ССР по термическому режиму]. Proc. Acad. Sci. Latvian SSR, No. 1 (234), 53-63 (in Russian).

Glazacheva, L. I. (1980). Hydrological Districts [Глазачева, Л. И. Гидрологическое районирование]. Latvian State University, Rīga. 44 pp. (in Russian).

Hammond, D., Pryce, A. R. (2007). Climate Change Impacts and Water Temperature. Environment Agency, Bristol, UK. 111 pp.

Hirsch, R. M., Slack, J. R. (1984). A nonparametric trend test for seasonal data with serial dependence. Water Res. Res., 20, 727-732.

Jurgelėnaitė, A., Kriaučiūnienè, J., Šarauskienè, D. (2012). Spatial and temporal variations in the water temperature of Lithuanian rivers. Baltica, 25 (1), 65-76.

Kaushal, S. S., Likens, G. E., Jaworski, N. A., Pace, M. L., Sides, A. M., Seekell, D., Belt, K. T., Secor, D. H., Wingate, R. L. (2010). Rising stream and river temperatures in the United States. Frontiers in Ecology and the Environment, 8, 461-466.

Libiseller, C., Grimvall, A. (2002). Performance of Partitial Mann-Kendall Tests for trend detection in presence of covariates. Environmetrics, 13, 71-84.

Liu, B., Yanga, D., Ye, B., Berezovskaya, S. (2005). Long-term open-water season stream temperature variations and changes over Lena River Basin in Siberia. Global and Planetary Change, 48, 96-111.

Martincova, M., Kučarova, K., Škoda, P., Pekarova, P. (2011). Long-term trend of water temperature in Slovak rivers. 25th Conference of the Danubian Countries on the Hydrological Forecasting and Hydrological Bases of Water Management, Budapest. Available at:

ftp://152.66.121.2/Floodrisk/_DC/docs/4_02_martincova\%20maria.pdf

Mihailov, V., Dobrovolskiy, A., Dobroliubov, S. (2005). Hydrology [Михайлов, В., Добровольский, А., Добролюбов, С. Гидрология]. Vysshaya Shkola, Moscow. 464 c. (in Russian).

Morisson, J., Quick, M. C., Foreman, M. G. G. (2002). Climate change in the Fraser River watershed: Flow and temperature projections. J. Hydrol., 263, 230-244.

Orr, H. G., Simpson, G. L., des Clers, S., Watts, G., Hughes, M., Hannaford, J., Dunbar, M. J., Laize, C. L. R., Wilby, R. L., Battarbee, R. W., Evans, R. (2014). Detecting changing river temperatures in England and Wales. Hydrological Processes, 29 (5), 752-766

Pekarova, P., Halmova, D., Miklanek, P., Onderka, M., Pekar, J., Skoda, P. (2008). Is the water temperature of the Danube River at Bratislava, Slovakia, rising? J. Hydrometeorol., 9 (5), 1115-1122.

Pekarova, P., Miklanek, P., Halmova, D., Onderka, M., Pekar, J., Kučarova, K., Liova, S., Škoda, P. (2011). Long-term trend and multi-annual variability of water temperature in the pristine Bela River basin (Slovakia). $J$. Hydrol., 400, 333-340. 
Poole, G., Risley, J., Hicks, M. (2001). Spatial and Temporal Patterns of Stream Temperature. Issue Paper 3. United States Environmental Protection Agency, 1. -35. pp.

Prats, J., Val, R., Armengol, J., Dolz, J. (2010). Temporal variability in the thermal regime of the lower Ebro River (Spain) and alteration due to anthropogenic factors. J. Hydrol., 387, 105-118.

Stakle, P., Kanaviņš, E. (1941). Latvijas iekšzemes ūdeņu hidrometriskie pètījumi no 1929. g. 1. XI lìdz 1940. g. 31. X [Hydrometric studies of the inland waters of Latvia from 1 XI 1929 to 31 X 1940]. Jūrniecības pārvalde, Rīga. 624 lpp. (in Latvian).

Toone, J. A., Wilby, R. L., Rice, S. (2011). Surface-water temperature variations and river corridor properties. IAHS-AISH Publication, 348, 129-134.

Uehlinger, U., Malard, F., Ward, J. V. (2003). Thermal patterns in the surface waters of a glacial river corridor (Val Roseg, Switzerland). Freshwater Biol., 48 (2), 284-300.
Van Vliet, M. T. H., Franssen, W. H. P., Yearsley, J. R., Ludwig, F., Haddeland, I., Lettenmaier, D. P., Kabat, P. (2013). Global river discharge and water temperature under climate change. Global Environ. Change, 23 (2), 450-464.

Van Vliet, M. T. H., Ludwig, F., Zwolsman, J. J. G., Weedon, G. P., Kabat, P. (2011). Global river temperatures and sensitivity to atmospheric warming and changes in river flow. Water Res. Res., 47 (2), 25-44.

Webb, B. W., Nobilis, F. (1995). Long term water temperature trends in Austrian rivers. Hydrol. Sci., 40, 83-96.

Webb, B. W., Walling, D. E., Zhang, Y., Clark, E. (1996). Water temperature behaviour in South-West England. In: Merot, P., Jigorel, A. (eds.). Hydrologie dans les pays celtiques. Rennes, France, pp. 53-64.

Xin, Z., Kinouchi, T. (2013). Analysis of stream temperature and heat budget in an urban river under strong anthropogenic influences. J. Hydrol., 489, $16-25$.

Received 30 November 2014

\section{LATVIJAS UPJU ŪDENS TEMPERATŪRAS ILGTERMINNA IZMAIN̦AS}

Pētījumā analizētas Latvijas upju virsūdeņu mēneša vidējā ūdens temperatūra (no maija līdz oktobrim) un gada maksimālā ūdens temperatūra no 1945. līdz 2000. gadam. Pētījuma rezultāti parādīja, ka novērojuma periodā no maija līdz oktobrim vidējā ūdens temperatūra augstāka lielajām Latvijas upēm (no 13,6 ${ }^{\circ} \mathrm{C}$ Gauja - Velēna HNS (hidrolog̣iskā novērojumu stacija) līdz 16,1 ${ }^{\circ} \mathrm{C}$ Lielupe - Jelgava HNS), bet zemāka temperatūra mazajām upēm (no $11,5{ }^{\circ} \mathrm{C}$ Amata - Melturi HNS līdz 15,6 ${ }^{\circ} \mathrm{C}$ Mūsa - Bauska HNS). Līdzīgas tendences novērojamas, ja analizējam maksimālo ūdens temperatūru: lielajām upēm no $22,7{ }^{\circ} \mathrm{C}$ (Gauja - Sigulda HNS) līdz $25,7{ }^{\circ} \mathrm{C}$ (Lielupe Mežotne HNS), bet mazajām upēm no 20,8 ${ }^{\circ} \mathrm{C}$ (Amata - Melturi HNS) līdz 25,8 ${ }^{\circ} \mathrm{C}$ (Mūsa - Bauska HNS). Kopumā zemākas ūdens temperatūras ir novērojamas upēm, kurām ir liela pazemes ūdeņu pieplūde, kā, piemēram, Gaujas baseina upēm, īpaši Amatas upei. Manna-Kendela tests parādīja, ka novērojuma periodā no maija līdž oktobrim vidējai ūdens temperatūrai galvenokārt ir novērojams pozitīvs trends $(22,2 \%$ gadījumos trends ir statistiski ticams pie $p<0.05)$. Savukārt, analizējot gada maksimālo temperatūru, tika iegūts galvenokārt negatīvs trends $(61,1 \%$ gadījumu trends ir statistiski ticams pie $p<0.05)$. 